\title{
Parliamentary Immunity: Protecting Democracy or Protecting Corruption?*
}

\author{
SIMON WIGLEY \\ Political Science, Bilkent University, Turkey
}

RECURRING question within contemporary democratic countries
relates to whether parliamentary immunity only serves to protect the interests of representatives, rather than the interests of those they were elected to represent. With every act that is suspected of being corrupt (for example, accepting a bribe in return for asking a question or delivering a speech in parliament, failure to declare campaign contributions, insider trading, nepotism etc.), or otherwise illegal (for example, defamation, drunk driving etc.), that is left unexamined by the courts, the justifiability of parliamentary immunity is brought into question. The problem posed by parliamentary immunity is that it affords each representative greater scope to pursue their own personal and political interests, over and above that which is made possible simply by their position of influence. As citizens it is this undemocratic possibility that might incline us to wish for the immunity to be curtailed. The political pressure to circumscribe the immunity is given added impetus by the prevailing public perception that political corruption is widespread. ${ }^{1}$ Indeed it is increasingly evident that a growing number of countries have either already reduced the scope of parliamentary immunity or are considering doing so. ${ }^{2}$ The principal rationale behind this trend is that the only telling way to prevent the decision-making

*This paper has greatly benefited from the critical input of John Charvet, Jürgen De Wispelaere, Jeremy Salt and the members of the Bilkent University Political Philosophy Group and London Political Theory Group. Thanks must also go to Ayhan Akkoyunlu.

${ }^{1}$ Michael Levi and David Nelken, 'The corruption of politics and the politics of corruption: an overview', The Corruption of Politics and the Politics of Corruption, ed. M. Levi and D. Nelken (Oxford: Blackwell, 1996), pp. 1-17 at pp. 3-4. Paul Heywood, 'Political Corruption: Problems and Perspectives', Political Studies, 45 (1997), 417-35 at pp. 417-21. Moreover, it is increasingly apparent that political corruption can no longer be taken as a phenomenon peculiar to non-Western European democracies. Levi, 'The corruption of politics and the politics of corruption', p. 1; Heywood, 'Political corruption', pp. 417-21. Witness, for example, the recent furore in the UK surrounding the claim that some MPs accepted cash payments in return for asking questions in the Commons (see Alan Doig, 'Cash for questions: Parliament's response to the offence that dare not speak its name', Parliamentary Affairs, 51 (1998), 36-50) and former German Chancellor Helmut Kohl's admission that he broke the law on party funding (a law put in place by his own government) by accepting undeclared donations and the possibility that they were accepted in return for political favours.

${ }^{2}$ Marc Van der Hulst, The Parliamentary Mandate (Geneva: Inter-Parliamentary Union Report, 2000), pp. 143, 150-2. 
process from falling prey to the quest for self-enrichment and election success is to render elected representatives vulnerable to the threat of legal inquiry and sanction.

Consider, however, the following case. In 1999 Fiona Jones, an MP for the Labour Party in the United Kingdom, was convicted for deliberately understating her election expenses. The prosecution argued that she had in fact spent twice the legal amount on her election expenses in the run-up to the 1997 general election. She was sentenced to 100 hours community service and, because of the conviction, automatically disqualified from her seat in parliament. The Court of Appeal subsequently overturned the conviction on the grounds that the trial judge misdirected the jury and there was no evidence to suggest that Jones had intended to deceive. ${ }^{3}$ In addition, the Court noted that that there were substantial grounds for viewing some of the witness evidence against Jones as guided more by political and personal animosity than empirical accuracy.

This leads us to ask whether exposing representatives to ordinary law is in fact a defensible position to hold. For in order to properly fulfill their role, representatives must be able to speak and act without fear of being subjected to a poorly conceived trial, imprecise or outmoded legislation, vexatious charges and so on. Thus, parliamentary immunity constitutes a far more perplexing issue for democratic theory than first impression might suggest. For, to the extent that elected representatives are immune from legal inquiry, they have more opportunity to either advance or abuse their designated function in representative democracy. The problem we are confronted with, therefore, is one of striking the right balance between protecting elected representatives from outside interference and limiting the possibility that they will neglect their democratic purpose.

In this paper I will seek to explore this issue by comparing two stylized models of parliamentary immunity: One which only bars the legal questioning of the immediate legislative agency of representatives (Legislative Agency Model), and another which, in addition, requires the consent of the representative assembly before the non-legislative agency of representatives can be legally questioned (Authorization Model). I will argue that the Legislative Agency Model fails to adequately protect the representative assembly from outside interference and displaces the supervisory role of the citizenry. In contrast the Authorization Model, if formulated correctly, requires civic involvement and provides a sufficient basis for both protecting the assembly and containing political corruption. On balance, therefore, the Authorization Model provides a superior basis for protecting and promoting representative self-government. At the very least the argument of the paper suggests that we should resist the political pressure to further expose elected representatives to direct examination

${ }^{3} R v$. Jones, 22 April 1999. According to the Court Jones clearly, and with good reason, believed that the non-disclosed expenses specifically related to what was used for local party purposes and were therefore not relevant to her individual election campaign expenses. 
by the courts. In the process of developing that argument the paper also aims to go some way to amend a gap in the literature: For, on close inspection, one is struck by how little political and legal scholars have attempted to investigate the justificatory arguments for parliamentary immunity. While there is no shortage of material on how parliamentary immunity is interpreted and applied within each country, there appears to be little or no treatment of how it might be justified as a component of democratic rule.

\section{TWO MODELS OF PARLIAMENTARY IMMUNITY}

In Article 9 of the 1689 English Bill of Rights it was declared, 'That the freedom of speech and debates or proceedings in Parliament ought not to be impeached or questioned in any court or place out of Parliament'. ${ }^{4}$ This formed the basis of the Legislative Agency Model dispersed to other countries by British colonial government (the exception to the rule being the Netherlands). Indeed the wording of the United States constitution's speech or debate clause (Article 1, Section 6) is almost identical to that of article 9: '[F]or any Speech or Debate in either House, they shall not be questioned in any other place'. ${ }^{5}$ The French National Assembly claimed the same protection in 1789. However, in the following year a significant addition was made to the immunity whereby representatives could not be incriminated without the authorization of the Assembly. ${ }^{6}$ It was from that basis that what I call the Authorization Model was developed and diffused throughout the remainder of the world's representative democracies.

In order to establish a more precise picture of what exactly differentiates the two models of parliamentary immunity, I will begin by considering the general meaning of 'questioning outside parliament'. First, what parliamentary immunity interprets as the form of outside questioning is those 'harms' that are required in order to execute the law of the land (for example, investigation, search, seizure, arrest, disclosure, prosecution, imprisonment etc.). Second, the source of outside questioning (that is, 'the questioner'), must be those entrusted with the power to juridically interfere (that is, the police, prosecutor, courts). Thus the electorate, press, pressure groups and so on denote different sources of outside questioning

\footnotetext{
${ }^{4}$ Although freedom of speech was already granted to the English parliamentarians, the Bill is significant insofar as it entrenched that privilege in statute. As a result it became explicitly part of the rule of law rather than a privilege that depended on the ongoing grace of the monarchy. For an overview of the historical development of parliamentary privilege prior to the Bill see G. R. Elton, The Tudor Constitution, 2nd edn (Cambridge: Cambridge University Press, 1982), pp. 265-68; J. P. Kenyon, The Stuart Constitution 1603-1688. 2nd edn. (Cambridge: Cambridge University Press, 1986), pp. 24 ff. and Erskine May, Parliamentary Practice: The Law, Privileges, Proceedings and Usage of Parliament, ed. Sir D. Limon and W. R. Mckay (London: Butterworths, 1997), pp. 68 ff.

${ }^{5}$ It seems that the form of parliamentary immunity that had been developed in Britain up to that point in time was accepted more or less wholesale in the US without discussion or opposition. US $v$. Johnson, 383 US 1691966 and Tenney $v$. Brandhove, 341 US 3671951.

${ }^{6}$ Van der Hulst, The Parliamentary Mandate, pp. 65, 79.
} 
which are not precluded by the immunity. Third and finally, what parliamentary immunity takes as the subject of outside questioning, what it is that is being protected, is the agency of the representatives rather than the decisions they reach. Thus the immunity does not encompass the institutional checks that may be imposed on the legislation determined by the representative assembly: namely, review by the judiciary and/or veto by the executive or other house. As with legislative supremacy, the general concern of parliamentary immunity is the ability of elected representatives to legislate without intervention by outside agencies. However, its specific concern is ensuring that those representatives are able to freely propose, debate and vote on laws rather than on their ability to formally enact them. A significant upshot of this is that the immunity creates a sphere of self-jurisdiction for, to the extent that legal scrutiny is precluded, only the assembly can adjudicate over the agency of its own members.

Despite this common background, the two explanatory models differ over what activities should be subject to legal questioning and whether that questioning should first obtain the permission of the representative assembly. According to the Legislative Agency Model, the subject of the immunity is the immediate legislative agency of the representatives. Take, for example, the way parliamentary immunity has been interpreted in the United States. The primary objective of the constitution's speech or debate clause is to leave those legislative activities leading up to a decision free from scrutiny by the courts (that is, they cannot be the cause or used in support of legal proceedings). Hence, the US Supreme Court has centered its interpretation of the clause on what it deems to be legislative activity: '.. . acts generally done in the course of the process of enacting legislation.... ${ }^{7}$ More specifically, press releases, newsletters, constituency work, and speeches delivered outside Congress are designated as 'political' rather than 'legislative' and, consequently, are illegible for immunity protection. In sum, all non-legislative agency, whether performed inside or outside the chamber, is directly vulnerable to legal examination. Although there is some variation as to what is deemed to be legislative agency, this convention closely parallels the way parliamentary immunity is interpreted and practised in the United Kingdom, India, Republic of South Africa, New Zealand, Republic of Ireland, Australia, Canada and the Netherlands. ${ }^{8}$ Significantly, legislative agency is unconditionally immune in the sense that the representative assembly typically does not hold the power to waive a representative's immunity.

${ }^{7}$ US $v$. Brewster, 408 US 501, 1972. See also the court's judgments in Kilbourn v. Johnson, 103 U.S. 168 1880; Tenney v. Brandhove, 341 U.S. 367 1951; United States v. Johnson, 383 US 169 1966; Gravel v. United States, 408 US 606 1972; United States v. Helstoski, 442 US 477, 1979; Hutchinson V. Proxmire, 443 U.S. 1111979.

${ }^{8}$ For a discussion of the intricacies behind the application of Article 9 in the United Kingdom, Australia, Canada and New Zealand see UK Parliament, Reports of the Joint Committee on Parliamentary Privilege in Session, 1 (1998-99) HL 43-I / HC 214-I at http://www.parliament.thestationery-office.co.uk/pa/jt199899/jtselect/jtpriv/43/4302.htm, ch. 2. For elsewhere see Van der Hulst, The Parliamentary Mandate, pp. 65-78. 
However, taking the immediate legislative agency as the defining characteristic of parliamentary immunity is the exception to the rule. The more prevalent Authorization Model affords protection to both the legislative and non-legislative agency of elected representatives. In keeping with the Legislative Agency Model, it accepts the need for an unconditional protection of the immediate legislative agency of representatives. However, those criminal activities that are not legislative in character are also rendered immune to any form of legal questioning unless authorized by the representative assembly. ${ }^{9}$ Members may still be arrested if caught flagrante delicto and those activities that are culpable with respect to civil law are often not immune from legal scrutiny. Unlike the unconditional immunity, the presumption is that a member can be legally questioned. ${ }^{10}$ In sum, the Authorization Model is composed of both an unconditional immunity whereby the immunity of legislative agency cannot be waived, and a conditional immunity whereby the immunity of 'criminal' non-legislative agency can be waived. ${ }^{11}$

It should be made clear that while representatives are the bearers of parliamentary immunity, the intended target is in fact their ability to act for the represented. Almost all immunities are designed to protect the function borne by the individual (for example, the diplomat, the trial witness, the judge, the sovereign, the executive etc.), rather than the individual herself. Indeed there may be no actual person who directly bears the immunity (for example, public interest immunity, discovery immunity etc.). The primary and perhaps only exception to that rule is the immunity entailed by individual rights.

What this means is that the function to be protected helps define the line between when the agency of the immunity-holder can and cannot be legally examined. That line is demarcated by a combination of the following parameters: 1. Type of Act (for example, a citizen may be free to express racial hatred, but not to physically harm another).

2. Time of Act (for example, whilst incumbent, the house is in session etc.).

3. Place of Act (for example, within a state's territory, church, representative chamber, household etc.).

4. Form of Legal Questioning (for example, investigation, arrest, entry and search, seizure, disclosure, self-incrimination, evidence, imprisonment etc.).

Each parameter may be used to qualify or expand the immune-space available to the immunity-holder so that the function may be best realized. With that

\footnotetext{
${ }^{9}$ That is to say, if the assembly exercises its power of waiver. It may be also argued that the assembly implicitly authorizes when it fails to exercise its power to suspend legal questioning.

${ }^{10}$ For two detailed studies of on this way of formulating parliamentary immunity and the different procedures that might be employed for waiving a member's immunity or suspending legal questioning against them see Allen Marilia Crespo, Parliamentary Immunity in the Member States of the European Community and in the European Parliament (European Parliament Directorate General for Research: Working paper no. W-3, 1993) and Van der Hulst, The Parliamentary Mandate, pp. 88-93.

${ }^{11}$ The unconditional immunity is also referred to as non-accountability, non-liability, privilege, or indemnity. The conditional immunity is sometimes referred to as inviolability.
} 
objective in mind, both models of parliamentary immunity offer competing ways of shaping the immune-space. The Legislative Agency Model stipulates that immediate legislative speech and action (typically performed while incumbent, while the assembly or committee is in session, and within the confines of the parliamentary buildings or committee meeting place) cannot form the basis of any form of legal questioning at any time. The Authorization Model, in addition, stipulates that non-legislative agency (performed whilst incumbent and in any place) cannot be subject to any form of legal questioning unless authorized by the assembly. As we will see, the difference in the way the two models shape the immune-space is essentially a consequence of the trade-off each draws between the possibility of outside intimidation and the possibility of political corruption; two possibilities that threaten the function of representation. Thus, the narrower Legislative Agency Model is more concerned with the latter possibility while the wider Authorization Model is more concerned with the former possibility. ${ }^{12}$

\section{REPRESENTATION AND CORRUPTION}

While all legal immunities provide the freedom to act, it does not necessarily follow that the immunity-holder should do all the things made possible by the immunity. The immunity allows the holder to act within the limits of the protected space, but it does not grant a moral right to act in any way that is made possible by it. In other words, while the formal immunity per se is neutral about what actions should be performed within the protected space, the reason for granting the immunity in the first place is not.

\section{A. THE FUnCTION OF REPRESENTATION}

In order to clarify what it is that parliamentary immunity is intended to protect and enable (or what it is that representatives have a moral duty to do), it will be necessary to establish a clearer understanding of the function of representation. To achieve that end I will briefly consider the sense in which the representative and the represented are 'present' in the democratic decision-making process. As Hannah Pitkin puts it, 'Representation means the making present of something

\footnotetext{
${ }^{12}$ Moreover, with the same issue in mind, each of the dimensions of the immune-space permits variation within each model. Thus in the case of the Authorization Model a representative democracy may, for example, require parliamentary authorization for some forms of legal questioning but not others. With respect to the timing of the alleged offence, a representative assembly may in some cases have the power to forestall the legal questioning of those acts performed before the member's mandate. See Crespo and Van der Hulst. Equally, each representative democracy, whether deploying the Legislative or Authorization Model, may interpret what constitutes legislative agency differently. The evidence given by non-members to a parliamentary committee is sometimes interpreted as legislative. But, defamatory or insulting statements made during parliamentary proceedings are often not unconditionally immune. While in Canada the courts have interpreted press releases and telegrams as legislative. Geoffrey Lock, 'The 1689 Bill of Rights', Political Studies, 37 (1989), 540-61 at p. 554. And so on. Despite these variations it is remarkable just how closely each of the world's representative democracies fits into one of the two models.
} 
which is nevertheless not literally there'. ${ }^{13}$ This suggests that a representative cannot make present her own personal or political interests, unless they happen to coincide with the interests of her constituents or nation (thus, self-interest per se does not contradict representation), without compromising her designated function. Put more precisely, the representatives should author laws and policy that the represented would author if they were present; that is, if they were just as proficient and knowledgeable and had spent the same time reflecting on the information and arguments presented to the assembly. ${ }^{14}$ The further idea being intimated here is that representatives are obliged to equally consider the points of view of the represented based on substantive merit; quality of argument as opposed to unquestioned opinion determines whether a citizen's views should be made present in the assembly's deliberations. For example, it may be argued that representatives should seek those arguments for deliberation in the assembly that, at least provisionally, appear to be justifiable to their fellow representatives and citizens. ${ }^{15}$ Consequently, the majority view in the constituency or nation, upon critical reflection, may not be considered as the most justifiable stance for the representative to take up and defend in the assembly. Representatives are independent, therefore, in the sense that they need not act on the direct instructions of voters. Equally, representatives are not independent in the sense that they can stray from what a citizen would do if they were to take part in the assembly's deliberations. What parliamentary immunity aims to protect and enable, therefore, is the ability of representatives to deliberate in place of the represented in spite of the fact that their argumentative positions may often depart from popular sentiment or the particular agenda of interest groups.

\section{B. Political CORRuption}

It should be conceded that an account of representation cannot avoid presupposing a particular conception of democracy. Thus, for example, the account advocated here leans towards a view of democracy that encourages reasoned public discussion over mere competition between a plurality of interests. ${ }^{16}$ Equally, an account of political corruption will be based on the account of representation thus derived. As Mark Philp notes it is only through

\footnotetext{
${ }^{13}$ Hannah Pitkin, The Concept of Representation (Berkeley: University of California Press, 1967), p. 144.

${ }^{14}$ Joseph M. Bessette, The Mild Voice of Reason: Deliberative Democracy and American National Government (Chicago: University of Chicago Press, 1994), pp. 34-6.

${ }^{15}$ Joshua Cohen, 'Deliberation and democratic legitimacy', The Good Polity: Normative Analysis of the State, ed. A. Hamlin and P. Pettit (Oxford: Blackwell, 1989), pp. 17-34 at pp. 22-25.

${ }^{16}$ Thus, this deliberative account of democracy seeks to revitalize some of the central tenets of the classical republican account of democracy. For a useful comparison between the different theoretical accounts of democracy as well as one way of construing deliberative democracy see Jürgen Habermas, 'Three normative models of democracy', The Inclusion of the Other: Studies in Political Theory, (Cambridge, Mass.: MIT Press, 1998), pp. 239-52. For discussions on what deliberation entails for representation see Bessette, The Mild Voice of Reason and Amy Gutmann and Dennis Thompson, Democracy and Disagreement (Cambridge, Mass.: Harvard University Press, 1996), chs 3-4.
} 
our understanding of what constitutes 'healthy politics', that which corrupt behaviour deviates from, that the concept of corruption derives its substantive content. ${ }^{17}$ Hence, the background theory of democracy defines the function or general principles of representative government, which in turn helps to define the ethical standards of conduct in public life that representatives ought to abide by. In other words, the background theory describes what it is to represent the public interest and, therefore, the duties of public office. ${ }^{18}$ Consequently, the account of representative democracy or uncorrupt representation we alight upon defines both what parliamentary immunity aims to protect and political corruption. Thus, based on the deliberative theory of representation outlined above, we can define corrupt representation in the following way. If the representative defends points of view (a) irrespective of argumentative merit and (b) for the gain of herself and/or the benefit of particular citizens, then she is failing to fulfill her function in the democratic process. She is favouring the particular interests of herself and/or others without due care for the justificatory force of those interests. That favouritism may be motivated simply by partiality to her own values, personal gain (status and wealth, for example, corrupt incentive) or political gain (political ambitions, for example, re-election prospects). ${ }^{19}$

The conundrum posed by parliamentary immunity is that it protects against the possibility of both uncorruptness (the function of representation) and corruptness (the neglect of the function of representation). This is because the formal immunity per se does not specify and enforce what it is that the representative ought to be doing. The extent of the agency made possible by the immunity-space outsizes the extent of the agency prescribed by the representative's public duty. It is only if and when ordinary law becomes relevant that we can consider legally enforcing the representative's public duty. Hence, so long as ordinary law is silent representatives can, if they so wish, pursue their personal gain ${ }^{20}$ and political gain (for example, illegal campaign financing, electoral fraud etc.) with impunity. In other words, to the extent of the immunity-space, we are dependent on the self-jurisdiction of parliament to enforce the public duty of representatives. The problem posed by self-jurisdiction however is that it falls prey to the charge that representatives should not be 'judges in their own case'. (I return to discuss this challenge in Section V.) In

${ }^{17}$ Mark Philp, 'The concept of corruption' Political Studies, 45 (1997), 436-62 at pp. 445-6. See also See Dennis F. Thompson, 'Mediated corruption: the case of the Keating Five' The American Political Science Review, 87 (1993), 369-81, in particular pp. 377-8.

${ }^{18}$ Philp, 'The Concept of Corruption', pp. 445-6.

${ }^{19} \mathrm{My}$ construal of corruption draws on Dennis F. Thompson's discussion of the distinction between political bribery and campaign contributions. Thompson, 'Mediated corruption'.

${ }^{20}$ With regard to parliamentary immunity it is more helpful to split personal gain into two categories: (a) wealth and status: e.g. receiving payments in return for making a speech in the assembly; embezzling public funds; benefiting from insider trading; providing lucrative government contracts for associates; nepotism and so on; (b) evading liability for harmful acts: immunity from prosecution for criminal acts (e.g. fraud, drunk driving, bodily harm etc.) and spoken or written words (e.g. libel, racial hatred, revealing the names of suspects in a trial and so on). In committing those illicit acts representatives violate the rights of citizens. 
addition it may be argued that the greater opportunity afforded by parliamentary immunity actually encourages corruption: either because it entices self-serving individuals into politics ${ }^{21}$; or because representatives find it too tempting to abuse the immunity once they are in office. The case for a narrower reading or even total abandonment of parliamentary immunity, therefore, rests on the mismatch between the immunity-space and the democratic ideals implied by the function of representation.

\section{PARLIAMENTARY INDEPENDENCE}

In Book II of Plato's Republic Glaucon argues that no one except a fool would behave justly if, in virtue of wearing Gyges ring, they were rendered invisible to the law of the land. People will only act justly if the threat of legal punishment means it is to their self-advantage to do so. ${ }^{22}$ The argument against a wider reading of parliamentary immunity outlined at the end of the previous section tends to view the bearers of parliamentary immunity in a similar, albeit less cynical, light. In the absence of legal compulsion, elected representatives may be motivated by personal or political gain to neglect their function (that is, promote points of view that lack substantive merit).

However, of equal concern is the failure to equally consider the justificatory merits of each point of view due to the application of legal pressure on representatives. In that case the neglect of substantive merit cannot be attributed to the venality of individual representatives or the absence of the law. Rather the possibility of this form of legal interference arises because of the failure or inability of the represented to properly deliberate. That is to say, (a) particular individuals, groups or institutions that lie outside the representative assembly are not motivated by the ideal of mutual justifiability or, (b) citizens lack the necessary time and information to adequately deliberate upon the issues at hand. In other words, the desire to juridically interfere emerges because the representative assembly will, after due deliberation, make decisions that it deems to be in the public interest (that is, acceptable to all if they were to likewise deliberate), but which is at odds with the unreflected viewpoint of the majority or the particular interests of powerful institutions and groupings within the polity. In that case the application of existing law undermines rather than compels the function of representation.

With that possibility in mind, parliamentary immunity aims to safeguard representatives by preventing individuals, the other powers of government,

\footnotetext{
${ }^{21}$ The extreme case of this would be where a person currently under criminal investigation also seeks to be elected in order to avoid prosecution and imprisonment. Moreover, an electoral candidate may use illicit acts in order to get into office (e.g. campaigning based on corruptly acquired money, electoral fraud etc.) and thereby obtain immunity against prosecution for those very acts.

${ }^{22}$ Plato, The Republic, trans. G. M. A. Grube (Indianapolis: Hackett Publishing, 1992), Book II, $358 \mathrm{e}-360 \mathrm{~d}$.
} 
fellow representatives, the popular majority, economic interests, and so on from falsely accusing or bringing trumped-up legal charges. Equally it prevents a judge or jury from interfering through the way they interpret the law. Finally, it protects representatives where the existing law is in itself unduly repressive; in that case it may be argued that the existing law itself is corrupt on the grounds that it fails to reflect higher-order normative principles (for example, equal consideration based on substantive merit). Clearly it is the enacted law per se, the judiciary and, if it appoints or in some way co-opts the judiciary, the executive, that poses the most direct threat here. Nevertheless, other outside interests can successfully bring charges if the law, its interpretation by the courts, or its implementation by the police favours them (that is, where the existing law coincides with their particular interests or they are in a position to influence the way it is implemented through cronyism, ability to pay court costs, bribery, intimidation and so on). The underlying suggestion here is that while the original reason for parliamentary immunity, namely intimidation by the executive, no longer appears to be as pertinent, the possibility of interference from other sources of power within the polity remains of paramount concern. What this means, I will argue, is that the protection afforded by the Legislative Agency Model is in fact insufficient.

Given the reasons why and the means by which legal interference may occur, we can now go a step further by specifying the ways in which parliamentary immunity helps to protect and promote representative democracy.

Inequality of influence: Generally speaking, parliamentary immunity grants representatives the deliberative space in which to equally consider the arguments at hand and to persuade voters of the merits of the decisions they reach. More specifically, the immunity entails that the legislative process is rendered invulnerable to those that are simply favoured by the existing law and its interpretation. Thus, parliamentary immunity helps to maintain the conditions for the equal consideration of the justificatory force of all points of view.

Displaced citizenry: Delegation to the law instills a culture of dependence on the courts and thereby deactivates the citizen body. Simultaneously, the citizenry are replaced by an electorally unchecked few (that is, judge and/or jury) who are, at the very least, as susceptible to partial judgment as a popular majority. ${ }^{23}$ (I expand on this point further in Section V.) This suggests that

\footnotetext{
${ }^{23}$ Jeremy Waldron, 'Judicial review and the conditions of democracy' Journal of Political Philosophy, 6 (1998), 335-55 at pp. 351-2. What is interesting to note in this regard is Ronald Dworkin's response to the Supreme Court's role in the 2000 United States presidential elections. Although Dworkin is well known as a champion of the role of a constitutional court in democratic rule, he argues he is yet to find any explanation other than 'professional self-interest' for why the conservative majority of the Supreme Court's members acted as it did when it effectively determined who would be the next president of the United States (i.e. they were more concerned with future Supreme Court appointments rather than accurately interpreting the constitution). Ronald Dworkin, 'A badly flawed election', The New York Review of Books, 11 January 2001, pp. 1-7 at p. 2. See also his exchange with Charles Fried in the 22 February 2001 issue of the same journal.
} 
we must be careful to ensure that an overdeveloped fear of political corruption does not lead us to frame parliamentary immunity in a way that lends itself to an overactive judiciary at the expense of an active citizenry. Separation of power: By providing a barrier against each arm of government intimidating the others' activities, parliamentary immunity helps to ensure that power does not gravitate to one place. It prevents one arm of government obtaining greater influence over another arm through the threat or pursuit of legal proceedings. ${ }^{24}$ I shall not venture here into the welltrodden debate as to what constitutes a suitable separation and balancing of powers. The point I am concerned with is that once the appropriate configuration has been arrived at, parliamentary immunity is relevant because merely delineating each institution's respective tasks is an insufficient obstacle against outside interference. ${ }^{25}$

Distraction and expense: Because it bars legal intervention, the immunity of parliamentarians helps to protect the ability of representatives to perform their duties without being distracted by court proceedings and expenses.

Significantly, each of these considerations remains relevant even if the enacted law is not overtly repressive; that is, even if the immunity protection afforded to representatives by ordinary individual rights is substantial. Where individual rights are poorly entrenched, the necessity of parliamentary immunity, I take it, simply becomes more pronounced. ${ }^{26}$

\section{THE LEGISLATIVE AGENCY MODEL AND LEGAL INTERFERENCE}

We may now ask whether the protection afforded by the Legislative Agency Model satisfactorily accommodates the reasons for parliamentary immunity discussed in the previous section. The problem, I contend, with excluding non-

\footnotetext{
${ }^{24} \mathrm{Although}$, as part of the same objective, each institution can often legitimately interfere by other means (e.g. control of finances, decision checks etc.).

${ }^{25}$ See James Madison, The Federalist, ed. J. E. Cooke (Middletown: Wesleyan University Press, 1961), No. 48.

${ }^{26}$ It may be further argued that parliamentary immunity is an important institution insofar as it provides the conditions necessary for the transition away from tyranny (i.e. authoritarian leaders are less able to arbitrarily arrest or prosecute reformist-minded parliamentarians). However, it may be claimed that the so-called less-developed democracies are also more prone to political corruption. Consequently, so the argument goes, our concern about the greater vulnerability of representatives to intimidation is balanced out by the need to protect against the increased likelihood that representatives will abuse their public office. In reply it may be argued that political corruption is itself conducive to the transition to democracy (e.g. because the hitherto excluded nouveau riche can buy themselves access. Samuel P. Huntington, Political Order in Changing Societies (New Haven: Yale University Press, 1968), pp. 59-71. These are issues that deserve far greater attention than can be achieved here. Hence, I shall continue to assume that our subject matter is established democracies.
} 
legislative activities from the immunity is that it leaves open the possibility of judicial encroachment and indirect interference. The concern in the first case is that the judiciary can encroach into the immunity-space through its interpretation of what constitutes legislative agency. ${ }^{27}$ Alternatively the assembly can, through self-imposed legislation, license the judiciary to question some aspects of its own legislative activity. The UK Joint Committee on Parliamentary Privilege, for example, has recently recommended that in cases of political bribery the courts should be able to question the legislative agency of representatives. ${ }^{28}$

The second area of concern is that while those who are favoured by the existing practice of law may not be able to intimidate the immediate legislative acts of representatives, they can certainly indirectly do so by threatening, or actually pursuing through the courts, vexatious charges or applying repressive law against what is interpreted as their non-legislative acts. Those who are already hell-bent on intimidating the decision-making process are hardly likely to be discouraged by the fact that the decision-making agency is in itself invulnerable. The implication of this is that the willingness of representatives to evaluate existing or future law and policy will be compromised as long as their non-legislative activities remain vulnerable. Similarly, for fear of legal proceedings a representative may be impelled into giving a particular speech in the assembly or voting in a particular way. Hence those individuals, groups and institutions favoured by the law can, through the threat or actual implementation of legal inquiry, indirectly influence the decision-making process according to their interests. Of greatest concern is the fact that the narrow reading of the immunity-space leaves exposed those acts that are clearly 'political' and in many cases integral to the function of representation, but which are not interpreted as 'immediately legislative' (for example, libel or sedition charges based on political speeches, constituency letters and newsletters, ${ }^{29}$ press communications, political

\footnotetext{
${ }^{27}$ It is standard practice amongst the world's representative democracies to delegate the task of interpreting what constitutes legislative agency to the courts. During the early development of parliamentary privilege in the UK there was an ongoing debate over whether the courts or parliament should decide when the immunity was applicable; that is to say, whether lex parliamenti was a component of, or entirely distinct from, common law. Eventually the debate was decided in favour of the court's jurisdiction. Erskine May, Parliamentary Practice, pp. 153-5.

${ }^{28}$ UK Parliament, Reports of the Joint Committee on Parliamentary Privilege in Session, paragraphs 166-9. Somewhat worryingly the Joint Committee made the proposal in spite of the fact that it both acknowledges the rarity of political bribery (paragraphs $140 \& 168$ ) and the fact that it is responding to the '...public perception that something is wrong which needs to be put right'. (paragraph 140, italics added)

${ }^{29}$ In 1797, for example, Samuel Cabell was prosecuted for sending to his constituents newsletters that were critical of the executive's handling of the war in France. Thomas Jefferson and James Madison responded by arguing that the intervention by the judiciary in such cases undermines the free communication that should take place between representatives and those they represent. See their 'Protest to the Virginia House of Delegates' in 1797, in Thomas Jefferson, The Works of Thomas Jefferson, ed. Paul Leicester Ford (New York and London: G. P. Putnam's Sons, 1904-5), pp. 326-7. Also quoted in the dissenting judgment of Justice Brennan, US v. Gravel, 408 U.S. 606, 1972.
} 
publications ${ }^{30}$ etc., or electoral fraud, as in the Fiona Jones case, accepting an illicit campaign contribution, partaking in a political march, membership of an organization etc.). Consequently, because of their jurisdiction over 'political' activities the courts (and those favoured by them) clearly remain in an immediate position to overawe the formulation of law and policy. Indeed, judicial encroachment entails that the courts have the power to determine what is within their ambit in the first place.

The threat posed by judicial encroachment and indirect interference is particularly acute with regard to the charge of political bribery, where, according to the Legislative Agency Model, ordinary law is relevant insofar as the legislative agency of representatives is not required as evidence in the trail. ${ }^{31}$ A representative can be charged with promising a future legislative act in return for a bribe (that is, where the bribery offence specifically relates to the representative's non-legislative agency rather than the legislative performance promised in exchange for the bribe), provided that his legislative speech and actions are not used in order to support the conspiracy charge. In effect nothing more than the difference between a promise and the enactment of the promise is used to define the perimeter of the immunity-space. Based on this fine cut a representative can be successfully convicted even if he did not actually fulfill the alleged promise. It is by no means clear, however, that the conspiracy charge can be satisfactorily established without referring to the legislative agency of the accused representative. The effect of the immunity may be to deny the accused representative a fair trial because he cannot refer to his legislative acts in order to cast doubt on the charges- he may, for example, not have actually performed the alleged promise, thus raising questions about whether a promise was actually made in the first place. Consequently, the representative is exposed to the possibility of conspiring witnesses, an over-zealous court or a poorly constructed trial and judgment. ${ }^{32}$

In addition, the court's legal interpretations in such cases may implicitly characterize the very nature and content of representative government. It is a matter of considerable debate, for example, whether and when a payment received for political but not personal gain can properly be called a corrupt

\footnotetext{
${ }^{30}$ Consider the infamous case of Member of Parliament John Wilkes, a thorn in the side of George III and his stooge Prime Minister George Grenville. After Wilkes published an article in his opposition newspaper The North Briton in 1763, George III and his ministers decided to prosecute him for seditious libel. He was arrested and thrown into the Tower but at a court hearing the Chief Justice ruled that, as an MP, Wilkes was protected by privilege from arrest on the charge of seditious libel. Nevertheless in the same year parliament voted that a member's privilege from arrest did not extend to the writing and publishing of seditious libels, thus rendering Wilkes vulnerable to prosecution. Peter D.G. Thomas, John Wilkes: A Friend to Liberty (Oxford: Clarendon Press, 1996), pp. 27 ff.

${ }^{31}$ See US v. Brewster, 408 US 501, 1972. But also see the dissenting judgments of White and Brennan. Reaffirmed in United States v. Helstoski, 442 US 477, 1979. And Harry Evans, ed., Odgers' Australian Senate Practice, 9th edn (Canberra: Department of the Senate, 2000), ch. 2, sec. 1.

${ }^{32}$ UK Parliament, Reports of the Joint Committee on Parliamentary Privilege in Session, paras 137, $158-9$.
} 
incentive. ${ }^{33}$ Former German Chancellor Helmut Kohl has steadfastly maintained that, while he broke the German campaign contribution laws, he was not acting corruptly in receiving undeclared funds on the grounds that he was acting in the interests of his party, rather than for his own self-enrichment. Even if we accept Kohl's word, however, that still leaves him open to the charge that the contributions were corrupt insofar as they granted his donors improper influence over decision-making. Given, as we have already seen, that the concept of political corruption derives its content from what is claimed to be healthy politics' (that is, uncorrupt representation), a court cannot reach a decision on what qualifies as 'improper' in such cases without presupposing a particular conception of representative democracy. Hence, if a court is more inclined to view democratic politics as a competition between a plurality of interest groups, it will be less concerned over the extent to which campaign contributions lead representatives to base their actions on the particular interests of donors rather than justificatory force. In effect ordinary law's jurisdiction over political bribery cases entails that an unelected few have some influence in defining the function of representation. Surely, the appropriate arena for working through the contested notion of representation is that of participatory politics? At the very least we should be concerned by the fact that a more involved judiciary displaces the citizenry from deliberating over the content of representative self-government.

Hence, an immunity that is restricted to the immediate legislative agency of representatives both fails to adequately protect the function of representation and leaves too much scope for the wrong forum to influence the definition of that function. This suggests that the scrutiny of representatives should be a matter, at least in the first instance, for electoral accountability rather than the courts.

\section{AUTHORIZATION AND ACCOUNTABILITY}

If we follow the argument of the paper thus far the conclusion we reach is that the Legislative Agency Model fails to adequately protect and promote democratic rule. It may be argued, nevertheless, that it constitutes a necessary trade-off because the function of representation is also threatened by the possibility that representatives will abuse their public duty. In this final section I will argue that the Legislative Agency Model does not in fact provide the optimal protection of representative self-government because the Authorization Model, appropriately formulated, is less susceptible to the possibility of political corruption than might be thought.

Electoral accountability by itself appears to be ill equipped to deter corrupt activity by representatives. Barring legal questioning and relying solely on retrospective voting would fail to dissuade some representatives from acting corruptly because the represented, and often the assembly itself, will lack

\footnotetext{
${ }^{33}$ See Thompson, 'Mediated corruption' and Philp, 'Defining political corruption'.
} 
sufficient information about each representative's propriety. ${ }^{34}$ That is to say, there would be no information-gathering agency such as the police which is both independent and bears sufficient investigative power. ${ }^{35}$ Moreover, the gains from corrupt activities will often outweigh the comparatively minor inconvenience of being elected out of office; and the threat of not being re-elected is often a feeble deterrent when compared to legal punishment. Given the absence of legal scrutiny and punishment, therefore, unscrupulous representatives will often not be discouraged from abusing their immunity.

How then can we preserve the integrity of the representative assembly whilst providing a sufficient disincentive to the possibility of political corruption? Is there a way to deploy the independent information-gathering resources of the police and/or prosecution service so that the electorate is adequately informed, and the deterrent effect provided by legal punishment, while still ensuring the independence of elected representation? I would argue that these objectives can be achieved if we let the assembly determine whether a member should be subject to the courts. This is precisely the approach employed by the Authorization Model of parliamentary immunity: namely, legal proceedings involving the nonlegislative activities of an incumbent representative must be sanctioned by the representative assembly. In effect, each representative's ability to nonlegislatively speak and act without fear of legal inquiry is conditional on the majority consent of the assembly. More specifically, the police or an extraparliamentary commission operates as an independent fact-finding agency. ${ }^{36}$ The information uncovered is then presented to the assembly for deliberation. ${ }^{37}$ As a

\footnotetext{
${ }^{34}$ For a general discussion of the problem of incomplete information and rent-seeking representatives see Adam Przeworski, Susan C. Stokes, Bernard Manin, 'Elections and representation', Democracy, Accountability and Representation, ed. A. Przeworski, S. C. Stokes and B. Manin (Cambridge: Cambridge University Press, 1999), pp. 29-54 at pp. 40-4.

${ }^{35}$ One alternative is to institute semi-independent 'accountability agencies' (e.g. an ethics committee) with the power to investigate representatives. Adam Przeworski, Susan C. Stokes, Bernard Manin, 'Elections and representation', p. 50 and Thompson, 'Mediated corruption', p. 378. However, it is difficult to see how such agencies can be granted sufficient independence and investigative power (interference by parliament and toothlessness was, for example, the common concern raised by all the parties involved in the UK cash for questions affair when investigated by the Parliamentary Commissioner for Standards, Sir Gordon Downey. Diana Woodhouse, 'The Parliamentary Commissioner for Standards: lessons from the "cash for questions" inquiry', Parliamentary Affairs, 51 (1998), 51-6), without merely replicating the police.

${ }^{36} \mathrm{O}$ the need for information-gathering that is not contingent on 'what governments want us to know' see Adam Przeworski, Susan C. Stokes and Bernard Manin, 'Introduction', Democracy, Accountability and Representation, ed. A. Przeworski, S. C. Stokes and B. Manin (Cambridge: Cambridge University Press, 1999), pp. 1-26 at p. 24 and Przeworski, Stokes and Manin 'Elections and representation', p. 50.

${ }^{37}$ In order to ensure that the information-gathering process is actually initiated it is crucial that all preliminary investigations should not themselves require prior authorization. Moreover, in order to overcome the problem of individuals seeking office simply in order to evade prosecution, it is essential that legal proceedings relating to pre-mandate activities should not require authorization or be capable of being suspended. However, as the Fiona Jones case shows, that should not include court proceedings relating to alleged electoral offences.
} 
consequence the assembly may discard the charges, internally sanction the representative, or waive her immunity such that criminal proceedings may be initiated.

Unlike the unconditional immunity of legislative agency, the conditional immunity of non-legislative agency grants the assembly the power to forgo its self-jurisdiction and delegate to the jurisdiction of the courts. Equally, unlike the absence of immunity protection, it precludes the possibility of direct intervention by the courts. Hence, the Authorization Model ameliorates the problem of judicial encroachment because the conditional immunity would always act as a precaution against legal interference. Similarly, the possibility of indirect interference is thwarted by the fact that ordinary law only has jurisdiction if authorized.

Significantly, the Authorization Model does not bypass civic involvement. Each allegation of political corruption becomes a matter for careful public deliberation by the assembly and, in virtue of electoral accountability, the citizenry. The law can only intercede if authorized by the representatives who are electorally accountable to the represented. In other words, it is the prior, or at least anticipated, intercourse between incumbents and voters which determines whether intervention by the law should occur in the first place. Citizens are encouraged to go beyond their merely reactive sentiment towards political corruption in order to consider and further develop their understanding of what constitutes uncorrupt representation. On this view any lag between the assembly's consideration of the case and the ballot box is beneficial because it grants voters the opportunity to be informed by the preliminary investigation, assembly deliberations and, if authorized, trial proceedings. ${ }^{38}$

The Authorization Model may, however, be challenged on the grounds that the power of waiver can be manipulated to the advantage of group interests within the assembly. A majority grouping can protect its own members from prosecution or subject minority members to the courts even though the allegations may be suspect. Equally a parliamentary grouping can extract voting agreements from representatives who are under threat of having their immunity lifted. What this suggests is that while representatives are formally equally immune, they may not be so in practice. Hence, the ideal of equal consideration based on substantive merit may be negated through the way the power of waiver is used in the chamber. In effect the point being made here is that in reality representatives tend to behave according to the competitive pluralist

${ }^{38}$ There is also much to be said for keeping the deliberations of the parliamentary committee and assembly secret until after any subsequent trial (e.g. delayed telecast) because representatives will then be less inclined to pander to popular sentiment (Gutmann and Thompson, Democracy and Disagreement, pp. 114-17 and Bessette, The Mild Voice of Reason, p. 146 \& pp. 206-9) and because it avoids the possibility of a subsequent trial being prejudiced (a concern raised by the UK Parliament, Reports of the Joint Committee on Parliamentary Privilege in Session, paragraph 156). 
rather than deliberative conception of representation. However, even if we concede that competitive pluralism at least partly explains assembly behaviour, ${ }^{39}$ that suggests that we should reconsider the design of government (that is, electoral and party political system, parliamentary committees and so on) in order to provide the institutional conditions that engender deliberation, ${ }^{40}$ rather than immediately opting for direct scrutiny by the courts.

Moreover, we should ask whether the Legislative Agency Model would leave us any better off in this regard. I take it that the underlying claim being made against the Authorization Model is that representatives should not be in a position to make judgments that will have a direct bearing on their political fortunes. We cannot trust our elected representatives to use the power of waiver in a deliberative way because, as John Locke puts it, '... it is unreasonable for men to be judges in their own cases, that self-love will make men partial to themselves and their friends'. ${ }^{41}$ Hence, or so the argument goes, the courts are required as an independent umpire. The problem with that inference is that it ignores the fact that judges are equally vulnerable to partial judgment (see the earlier discussion in Section III). They too are 'judges in their own case', for the views of the accused parliamentarian may or may not cohere with the judge's ideological leaning, preferred political party, moral outlook, and so forth. ${ }^{42}$ Perhaps the possibility of judicial partiality may not be viewed as a significant problem where ordinary citizens are concerned, but where the accused is directly involved in national decision-making the issue cannot be ignored. Moreover, we cannot avoid the obvious fact that, unlike their parliamentary counterparts, judges are not answerable to the electorate. Sure, judges and juries are supposed to interpret and apply the law dispassionately, but what at the end of the day ensures that they actually will?

It should also be noted that the possibility of majority self-protection and vote bargaining is not as likely as it might first appear. This stems from the fact that the Authorization Model has the effect of shifting the focus of electoral scrutiny away from the accused representatives per se to their fellow representatives (that is, those parliamentary groupings who are in a position to seek a vote bargain

\footnotetext{
${ }^{39}$ While there is not enough space here to consider in depth the way the Authorization Model is actually practised, it seems safe to assume that non-deliberation must at least partly explain what actually occurs. But equally it seems safe to assume that deliberation also partly explains the process of authorization. Indeed, Joseph Bessette argues that the legislative process in the US Congress is more often characterized by reasoned argument than bargaining. Bessette, The Mild Voice of Reason, chapters $4 \& 5$.

${ }^{40}$ See for example Brian Barry, Justice as Impartiality (Oxford: Oxford University Press, 1995), sec. 16, esp. pp. $105-8$.

${ }^{41}$ John Locke, The Second Treatise of Government, in Political Writings, ed. D. Wootton (London: Penguin, 1993), ch. 2, sec. 13, p. 267.

${ }^{42}$ See Jeremy Waldron, 'Judicial Review and the Conditions of Democracy', pp. 349-50. It may be argued that the partiality of court judgments is only really a problem in code law-based countries, where there is no jury and the judge is not construed as an impartial umpire. But that neglects the fact that, in case law-based countries, the key precedent-setting judgments with regard to parliamentary immunity are made by constitutional or high court judges.
} 
with the accused). ${ }^{43}$ Because the represented eventually have access to the findings of the independent investigation (that is, the members of the assembly cannot 'manage' the information available to the public), and the subsequent assembly deliberations, the authorizers will be acutely aware of the electoral repercussions of failing to waive the immunity of a person suspected of a serious offence; or, worse still, forming a voting alliance with them. If such investigative agencies are in place, then those activities that an informed electorate consider as ineligible for protection will have a significant bearing on whether a representative's immunity is waived. Equally, if the assembly waives the immunity of a representative on grounds that lack substantive merit (for example, simply because she is critical of her fellow parliamentarians) the authorizers are also left vulnerable to the electorate which is, in addition, informed by the subsequent court proceedings.

What I have argued for here is at odds with the received wisdom in those countries that have taken Article 9 of the English Bill of Rights as their point of departure. Indeed the prevailing inclination throughout the world's representative democracies is that we should, if anything, curb parliamentary immunity in order to bridle self-serving representatives. I have argued, to the contrary, that a close inspection of the nature and practice of parliamentary immunity reveals that a wide reading of that immunity that is sensitive to accountability provides us with a more defensible strategy for accommodating the tension between political corruption and parliamentary independence.

\footnotetext{
${ }^{43}$ Significantly, where the focus of attention is political parties rather than corrupt individual representatives, the evidence suggests that electoral accountability is not wholly ineffective. Ian McAllister, 'Keeping them honest: public and elite perceptions of ethical conduct among Australian legislators', Political Studies, 48 (2000), 22-37 at p. 25.
} 